\title{
PLASMA CELL MYELOMA OF THE ORBIT*
}

BY

\author{
EDWIN CLARKE
}

\section{London}

THE manifestations of multiple myelomatosis are legion and in a small number of cases the orbit is involved. They present clinically as orbital space-occupying lesions and have been dealt with briefly elsewhere (Clarke, 1953), but no collective study of them is available, and the object of this paper is to review the problem and record two illustrative cases.

Myelomatosis is characterized by plasma cell tumours-myelomata or plasmacytomata-growing usually from the bone marrow but occasionally from extra-osseous tissues. Clinically the patient has generalized fatigue, loss of weight, anaemia, bone pains, and pathological fractures. Death occurs after an average survival of 2 years, in spite of any known treatment. $X$ rays show typical osteolytic bone lesions, the urine frequently contains Bence Jones protein, the plasma globulin and blood sedimentation rate are increased, and a bone-marrow biopsy usually reveals an increase of plasma cells. This is the classical picture but there are several variants, ranging from a process that is fatal in a few months, to one in which the patient may survive for years. The "solitary" myeloma belongs to this latter group and was at one time thought to be a separate clinical entity. By the use of bonemarrow biopsy, extended follow-up, and detailed post-mortem studies, however, it has in almost all cases been proven to be but a stage in the generalized disease and almost invariably other evidence of myelomatosis may be found if it is looked for very carefully. It is maintained by some that a truly solitary lesion indistinguishable from the multiple tumour does sometimes occur (Cristopherson and Miller, 1950).

It is necessary to differentiate between the plasma cell myeloma of myelomatosis and the benign plasma cell tumour produced by chronic inflammation. Unfortunately, they are both termed "plasmacytoma" or "plasmocytoma", and there is considerable confusion in the literature concerning this important point. Their differentiation both clinically and histologically is not usually difficult but is obviously of great importance for prognosis and therapy. In this paper the term "plasmacytoma" has been reserved for the non-myelomatous, granuloma-type masses, and "plasma cell myeloma " or "myeloma" for the tumours associated with myelomatosis. Plasmacytomata (or, as they are sometimes called, plasmomata) grow from the conjunctiva, cornea, lids, and lacrimal gland or sac, as well as from the mucosa of the upper air passages, and are in no way related to multiple myeloma. Certain cases of orbital plasma cell tumours found in the liter-

- Received for publication May 7, 1953. 
ature have been rejected as examples of myelomata because of their doubtful origins. Despite the opinions of the authors concerned, the cases of Parker (1937) and François, Kluyskens, and Rabaey (1949) have been excluded. There is some evidence that the orbital mass in each case was a true myeloma and not a granuloma such as Przyblyska (1924) described, but neither report includes information concerning full investigations, progress nor autopsy. Walsh (1947) could not be certain that the tumour in his patient was not a pseudotumour and the case therefore has not been included.

A special type' of granuloma, the eosinophilic granuloma, has also let to confusion, and the case published by Krümmel (1950), in an article entitled "Eosinophiles Myelom (Plasmozytom)", was undoubtedly of this nature Its occurrence in the orbit was described by Beller and Kornblueth (1951).

\section{INCIDENCE}

The exact incidence of myeloma of the orbit is difficult to discover, for those dealing with orbital tumours are unlikely to see all cases of myelomatosis with this complication. Authors who have reviewed multiple myeloma do not mention it, and it is possible that in the past the myeloma has not been differentiated from kindred neoplasms. Thus, Birch-Hirschfeld (1930) in an exhaustive treatise on orbital tumours does not mention it directly, but includes an occasional case with other types of tumours. A measure of its rarity, however, can be obtained from the fact that Forrest (1949), reviewing 222 intra-orbital tumours, found only one "plasmocytoma" (myeloma), and that there were two myelomata in a series of 676 tumours described by Offret (1951). Pfeiffer (1941) had only one example among 200 cases of exophthalmos. The absence of myelomata is specifically noted by Godtfredsen (1947) when dealing with 78 cases of orbital tumour, representing 10,000 admissions to an ophthalmological clinic in 15 years.

\section{Classification}

Cases of myelomatosis with orbital involvement fall into two groups:

A. Primary myeloma of the orbit. The patient presents with ocular features, suggestive of an orbital tumour.

B. Secondary myeloma of the orbit. The patient has a para-orbital myeloma and eventually develops symptoms and signs of an orbital tumour due to orbital invasion.

Some of the cases in the literature, however, cannot be so grouped because of a paucity of information concerning them (Grosz, 1927; Verhoeff, 1939; Pfeiffer, 1941; Godtfredsen, 1944, Table XXX, Case 18; Forrest, 1949; Bichel, 1950, Case 6). It is possible, of course, that they were not all true plasma cell myelomata. The case of Elizabade. quoted by Scheinker (1938), could not be traced, and his statement (Scheinker, 1951) that the first case of myeloma had orbital involvement and was described by Burns (1824) is not correct; the case in question is the first example of chloroma.

A. Primary Myeloma of the Orbit.-The literature includes at least thirceen cases of orbital myeloma where the information given is sufficient to place them definitely in this group (Table). Only undoubted myelomata have been accepted and other evidence of myelomatosis was present in all of them. 


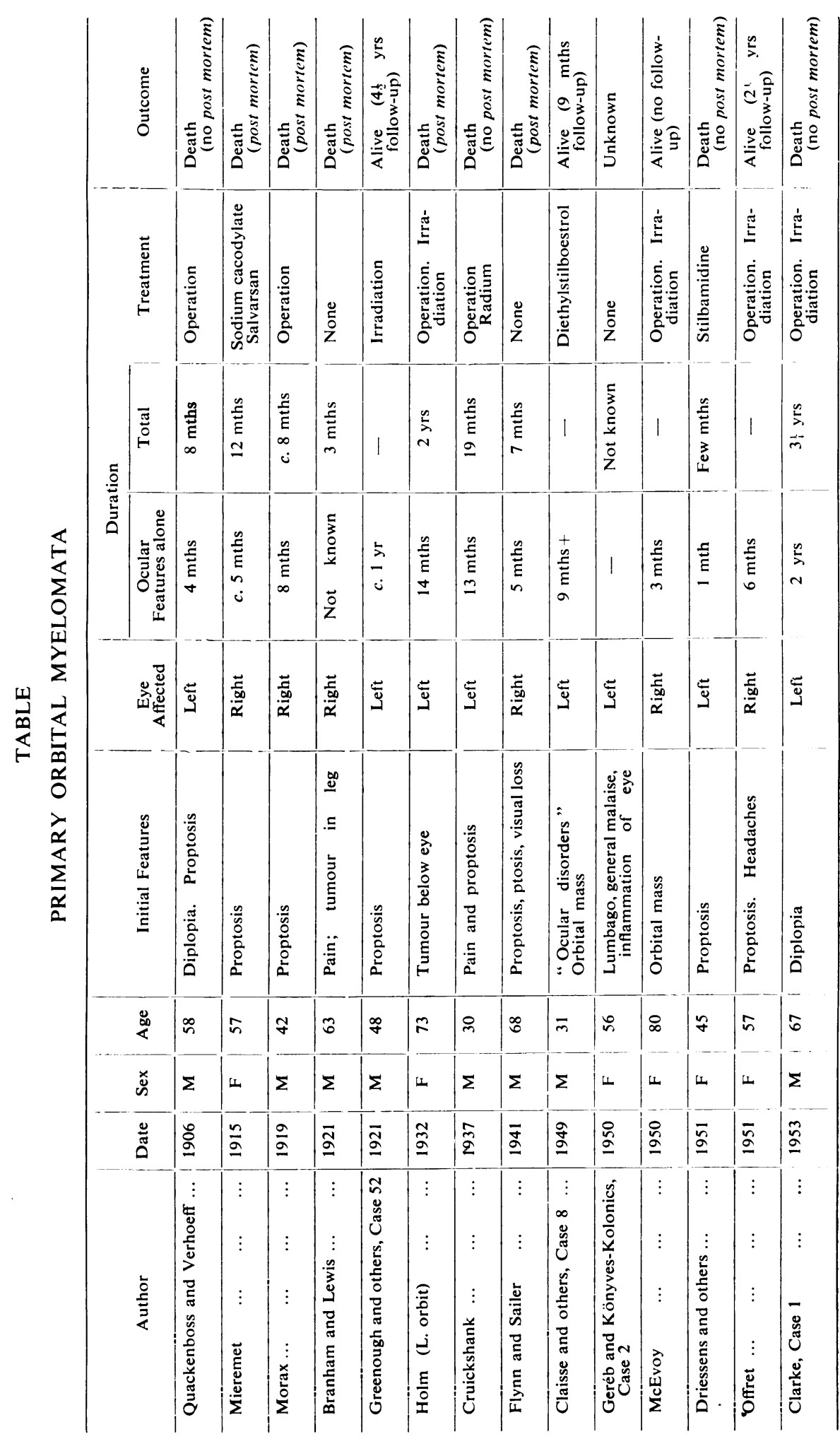

응

을

$\stackrel{\vec{F}}{\stackrel{9}{9}}$

을 क

送 क

co

c

옥

$\vec{\omega}$

$\frac{\mathbb{D}}{0}$

음

융

흑잉

క

ֻำ

임

옥

륭

흥.

훙.

을

옥

을.

Nั

옹

స్ట

ర్ర

$\stackrel{0}{\mathbb{D}}$

꿍 
To the cases shown in the Table, another may be added.

\section{Case 1, male, 67 years.}

One year of diplopia, 2 months of left ptosis and proptosis. Left supraciliary mass and $X$-rays showed osteolytic lesions in this and other regions. Partial removal of left orbito-o frontal tumour (verified as myeloma) and radiation therapy given, but generalisation and local recurrence occurred. Death. Total survival $3 \frac{1}{4}$ years. No autopsy.

This patient, a butcher by trade, was admitted to the Radcliffe Infirmary, Oxford, on May 18, 1949, under the care of the late Sir Hugh Cairns. One year before admission he noticed double vision which was constantly present and most marked when looking $\mathbb{\mathscr { \Phi }}$ downwards. For 2 months there had been progressive drooping of the left upper lid ando slight protrusion of the eye.

Examination.-General condition good. Slight proptosis of the left eye, the globe being pusheddownwards and slightly laterally. In the left supraciliary region there was a firm, non-tender $\vec{\sigma}$ mass, and a similar lesion was palpable in the right occipital region.

Visual acuity right eye $\mathbf{J 1}$, left eye $\mathbf{J} 2$ (uncorrected).

Optic fundi, visual fields, and pupils all normal. Upward movement and adduction of left eye. slightly limited, with production of diplopia in all directions.

Central nervous system and other systems normal.

Investigations

$\mathrm{X}$ rays of skull showed a large area of bone destruction in the left frontal region extending $\overrightarrow{ }$ to the orbit, and similar but much smaller areas elsewhere (Fig. 1).

Urine, no Bence Jones proteinuria.

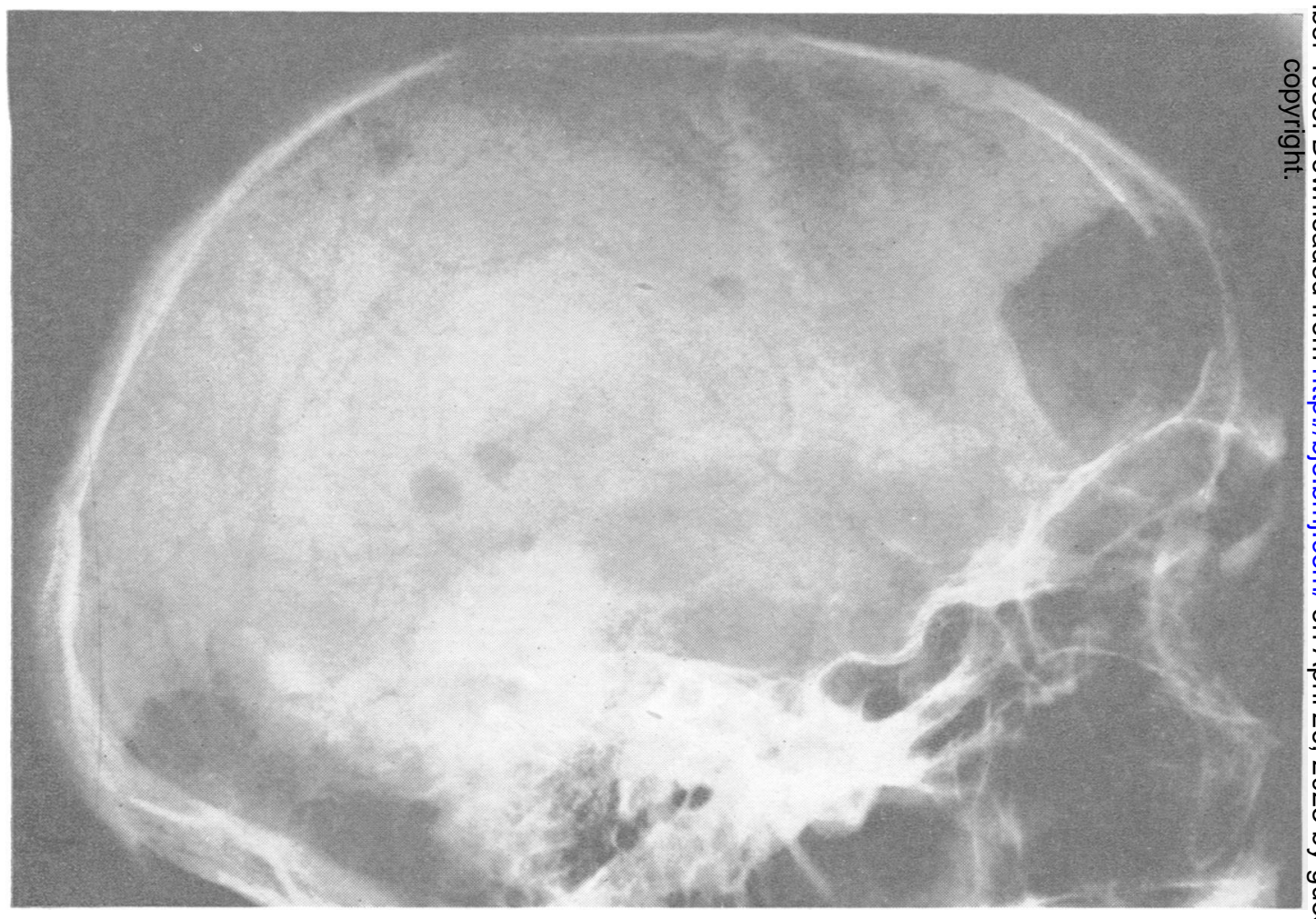

Fig. 1.-Case 1, $x$ ray of skull showing large left orbito-frontal myeloma and smaller ones elsewhere.

Operation (Mr. J. B. Curtis) May 26, 1949.- Soft vascular tumour found in left supra $\frac{\mathbb{D}}{\mathrm{O}}$ ciliary region; much of the orbital roof on this side had been destroyed; tumour tissue in the orbit. Only partial excision was possible. 
Histology.-The material removed had the microscopical appearance of a myeloma (Fig. 2).

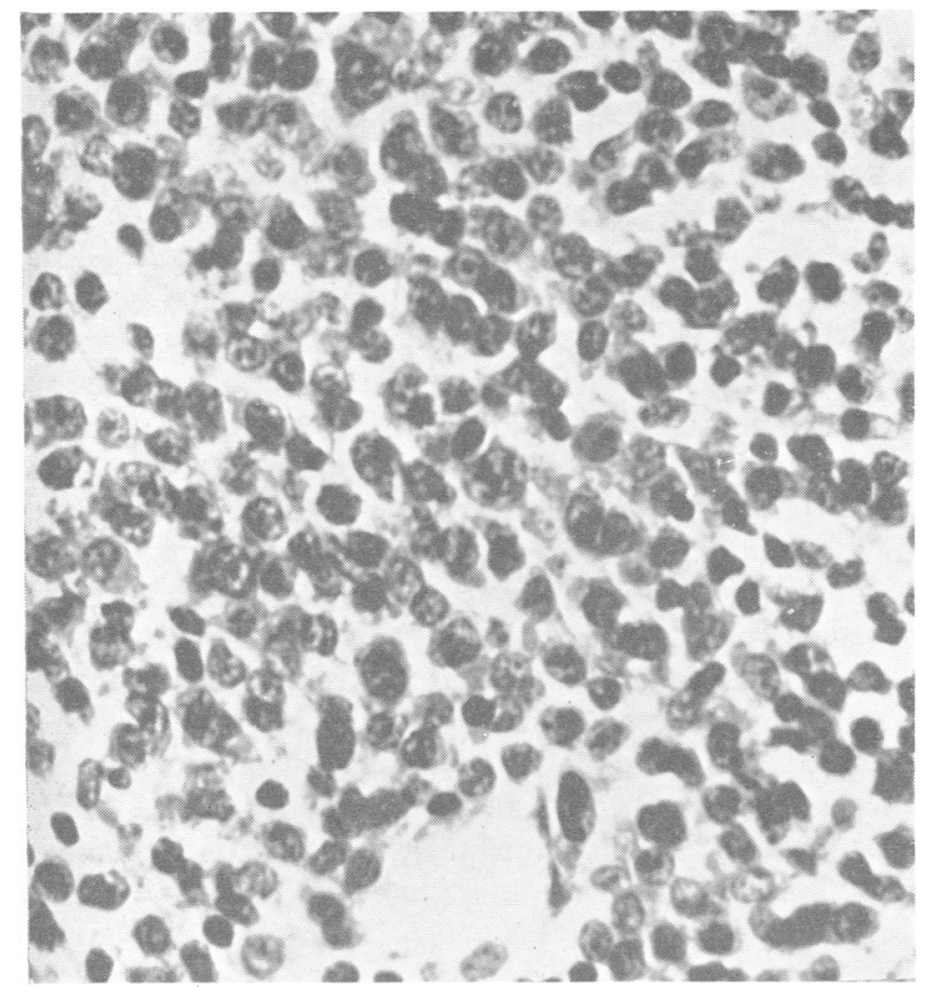

Fig. 2.-Case 1, photomicrograph of myeloma. The principal elements are plasma cells. $(\times 580)$

Progress.-The patient made a good post-operative recovery and was given three courses of deep $x$-ray therapy directed to the left orbital region. The proptosis and diplopia disappeared and he was discharged on June 3,1949. A year later, he was found to have a myelomatous deposit in the 6th thoracic vertebral body, and 6 months after this noticed the return of proptosis, ptosis, and diplopia. He was given another course of radiation therapy but after 6 months his condition had deteriorated further. He now had evidence

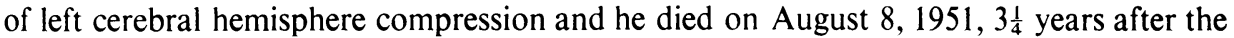
onset of the disease. It was not possible to carry out an autopsy.

Comment.-This was a typical case of multiple myeloma presenting with ocular features due to an orbital myeloma that had presumably spread to the frontal bone. Its exact site of origin cannot be determined but may have been the contents or roof of the orbit. Partial removal and irradiation produced only temporary improvement and the classical course of the disease was observed.

Pathology.-The myeloma in these cases apparently grows from the orbital contents or walls, but at a late state of its development it is usually impossible to identify the structure from which it arose. Morax (1926) thought that this was invariably the roof of the orbit, but Flynn and Sailer (1941) noted that in their case the tumour was limited to the contents of the orbit and that its confines were intact. In addition, no $x$-ray evidence of bony erosion could be found in the cases of Claisse, Bonduelle, and Lavergne (1949, Case 8), McEvoy (1950), and Offret (1951). The primary myeloma may thus be a product of the orbital contents and therefore of extra-osseous origin; unfortunately there seems to be no information con- 
cerning the actual tissue that is initially responsible. Frequently the tumour eventually destroys the surrounding bone(Mieremet, 1915; Morax, 1919; Holm, 1932; Case 1 above), and it may extend through the roof and compress the under surface of the frontal lobe of the brain as in the cases of Morax (1919), Branham and Lewis (1921), Holm (1932), and Case 1, above.

Clinical Picture.-In all but one of the fourteen cases, symptoms referable to the eyes were either the earliest, or amongst the earliest, manifestations of the disease. The commonest complaint was that of progressive protrusion of an eye, the globe being displaced in any direction. Whereas malignant orbital neoplasms usually present with ocular immobility, proptosis is much commoner as an initial symptom in these cases of plasma cell myeloma. Occasionally the tumour can be palpated within the orbit and is of a firm consistency but never tender. Reduction of the eye is rarely possible and marked pulsation does not occur. The next most common feature is impairment of vision which varies from total blindness to only slight involvement; the mechanism of its production has not been investigated. Diplopia due to restricted ocular movements is less frequent and papilloedema and pupillary changes have been only rarely mentioned. Unfortunately clinical details in several reports are scanty; no accounts of visual fields nor detailed fundus examinations are available. Unlike other malignant orbital neoplasms, and plasma cell myelomata elsewhere, pain is rarely experienced. It is important to note that in twelve cases these clinical features were the initial manifestations of multiple myelomatosis, being present alone for several months (1 to 24 , average 8 ). When other evidence of myeloma appeared, the process usually proceeded to the rapidly fatal termination that is to be expected in this disease. The shortest duration was 3 months (Branham and Lewis, 1921) and the longest $4 \frac{1}{2}$ years (Greenough, Simmons, and Harmer, 1921, Case 52). The latter case is an example of one of the variants of myelomatosis where the course of the disease is slower than in the classical type. If this case be excluded, the average survival of the patients with primary orbital myelomas (eight cases) was 15 months. Four were still alive when reported, the longest follow-up being that of Greenough and others (1921).

Diagnosis.-A myeloma should be considered if an orbital tumour produces bony destruction. The investigations mentioned above should always be carried out in order to find evidence elsewhere of myelomatosis. Biopsy clinches the diagnosis.

Treatment.-There is no cure for multiple myelomatosis, and only palliative measures are available. Three main methods of therapy exist: histiotoxic drugs, irradiation, and surgery. Of the drugs, stilbamidine, nitrogen mustard, and radio-active phosphorus have given disappointing results, although the former frequently relieves pain and the latter may produce subjective improvement. Although it is too early to evaluate them adequately, no striking effects have been noted either with ACTH or cortisone. Experiences with urethane have been a little more encouraging (Luttgens and Bayrd, 1951), but toxic manifestations are common. Radiation therapy seems to have definite beneficial effects upon local lesions but it is doubtful if it influences the generalized disease. Surgery has a limited application and its scope is dependent upon the location and size of the myeloma.

Of the nine patients with primary orbital myelomata (Table) that are known to have died, two had no treatment, two had medical therapy with no effect upon the course of the disease, and five were operated upon but only partial removal of the 
tumours was possible and recurrence occurred in each instance despite the addition of radiation therapy in three. The surviving patients were given irradiation, either alone or supplemented with surgery. The best form of therapy, however, is probably a judicious combination of the three modes. Only partial surgical removal of an orbital myeloma would in most cases be possible, but this would be followed by deep $x$-ray irradiation and a course of urethane. All other measures aimed at decreasing the patient's discomfort should, of course, be employed. Active treatment of the orbital lesion would only be resorted to if it alone was producing symptoms or the disease was only slowly progressive and the patient's general condition and expectation of life warranted it. Nevertheless, one gains the impression that the eventual outcome is dependent not upon the therapeutic agents employed but upon the predetermined course of the disease as a whole.

B. Secondary Myeloma of the Orbit.-In these cases, the primary focus is in the para-orbital structures-cranial bones, paranasal air sinuses, nose, or nasopharynx - and the orbit is encroached upon secondarily. Again, if the case is seen at a late stage, it may be impossible to say which structure was affected first, but the initial features of the illness are usually suggestive. Myelomata of tissues adjacent to the orbit will be dealt with in turn.

Cranial bones.-The bones of the cranium are said to be involved in over 70 per cent of cases of myelomatosis (Bayrd and Heck, 1947) and it is therefore not surprising that occasionally a myeloma is found to extend into the orbit. Lesions in the temporal region, which entered the orbit to produce ocular symptoms and signs, have been described by Rustizky (1873), Ribbert (1904), de Harven, Murdoch, and Cahen (1927), Ferrand (1951), and Pages, Betoulières, and Cazaban (1952). Similarly, frontal bone myelomata invading the orbit occurred in the cases of Lecène (1919), Dick (1904), Lapointe (1929), Ibañez Puiggari, Balado, and Gaviña Alvarado (1930), Geréb and Könyves-Kolonics (1950, Case 1); and probably those of Duc (1937) and Krainin, D'Angio, and Smelin (1949), also had orbital extensions. In Case 1 above, the events were reversed and the frontal bone was invaded after the orbit. The end result, however, is the same and the only method of differentiating the two groups is by the clinical information. The following case illustrates this type of orbital involvement.

Case 2,* female, 60 years.

Headache for 9 months following left frontal injury. Left frontal, osteolytic tumour with left ptosis and proptosis for 3-4 months. Biopsy revealed myeloma. Bence Jones proteinuria. Partial removal with development of coma and right hemiplegia, not influenced by further decompression. Death. Total survival about 9 months. Autopsy. Myeloma involved sinuses and orbital roof.

A housewife aged 60 years was admitted to the London Hospital on March 24, 1938, under the care of the late Sir Hugh Cairns. Nine months before admission she fell and struck the left side of her head but did not lose consciousness. Thereafter she suffered headaches which were mainly left frontal. For 3-4 months, there had been a swelling of the left forehead, the left eye was slightly more prominent and the upper lid was drooping. Recently she had been less alert mentally but had no other symptoms.

Examination.-A slightly obese, cheerful woman, in no apparent distress. A mass $11 \mathrm{~cm}$. in diameter occupied the left frontal bone. Its elevation above the skin surface was slight but it

*This case is Case 4 of Clarke (1953). 


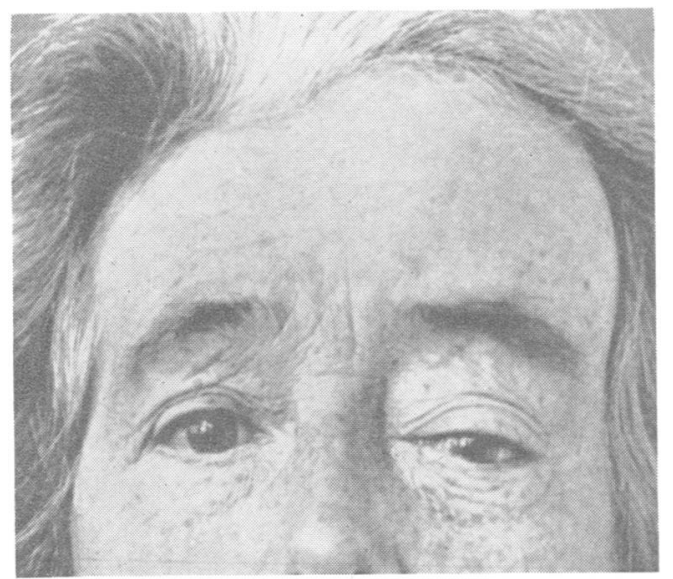

Fig. 3.-Case 2, myeloma of left frontal bone can be seen as well as ocular features. extended down to involve the supra-orbital region and upper orbit. It was slightly tender, fluctuant, and a distinct systolic bruit, which could be obliterated by pressure on the ipsilateral carotid artery, was heard over it. The irregular edge of a cranial defect could be felt beneath. There was slight proptosis and ptosis on the left and a fullness above the eye (Fig. 3).

Visual acuity, both eyes $6 / 18$ and $\mathrm{J} 1$ (corrected).

Optic discs and fields normal. Left pupil slightly smaller than the right but had normal reactions; upward and lateral movements of left eye restricted.

Central nervous system and other systems normal.

Investigations

$\mathrm{X}$ rays of skull showed extensive destruction of left frontal region extending to left orbit (Fig. 4); chest normal; long bones normal.

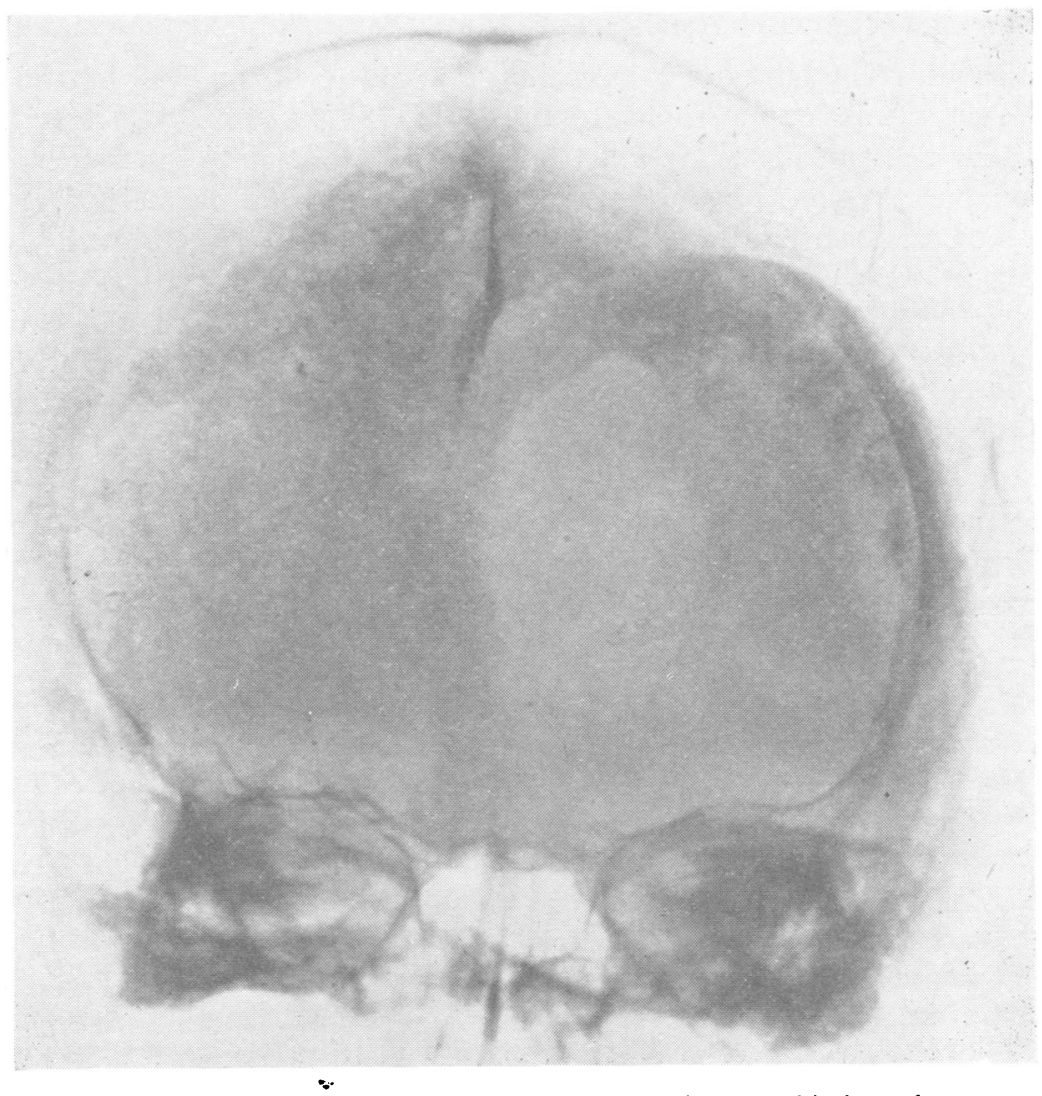

FIG. 4.-Case 2, $x$ ray of skull showing large fronto-orbital myeloma.

Cerebrospinal fluid pressure $140 \mathrm{~mm}$.; cells 1; protein $25 \mathrm{mgm}$. per cent; Lange no-change; Wassermann reaction negative.

Blood haemoglobin 94 per cent; white cells 8,960 (differential count normal).

Urine: Bence Jones protein present.

Biopsy (30.3.38) Mr. J. B. Pennybacker. Tissue removed from skull tumour reported by Professor D. S. Russell as being diagnostic of a myeloma (Fig. 5, opposite). 


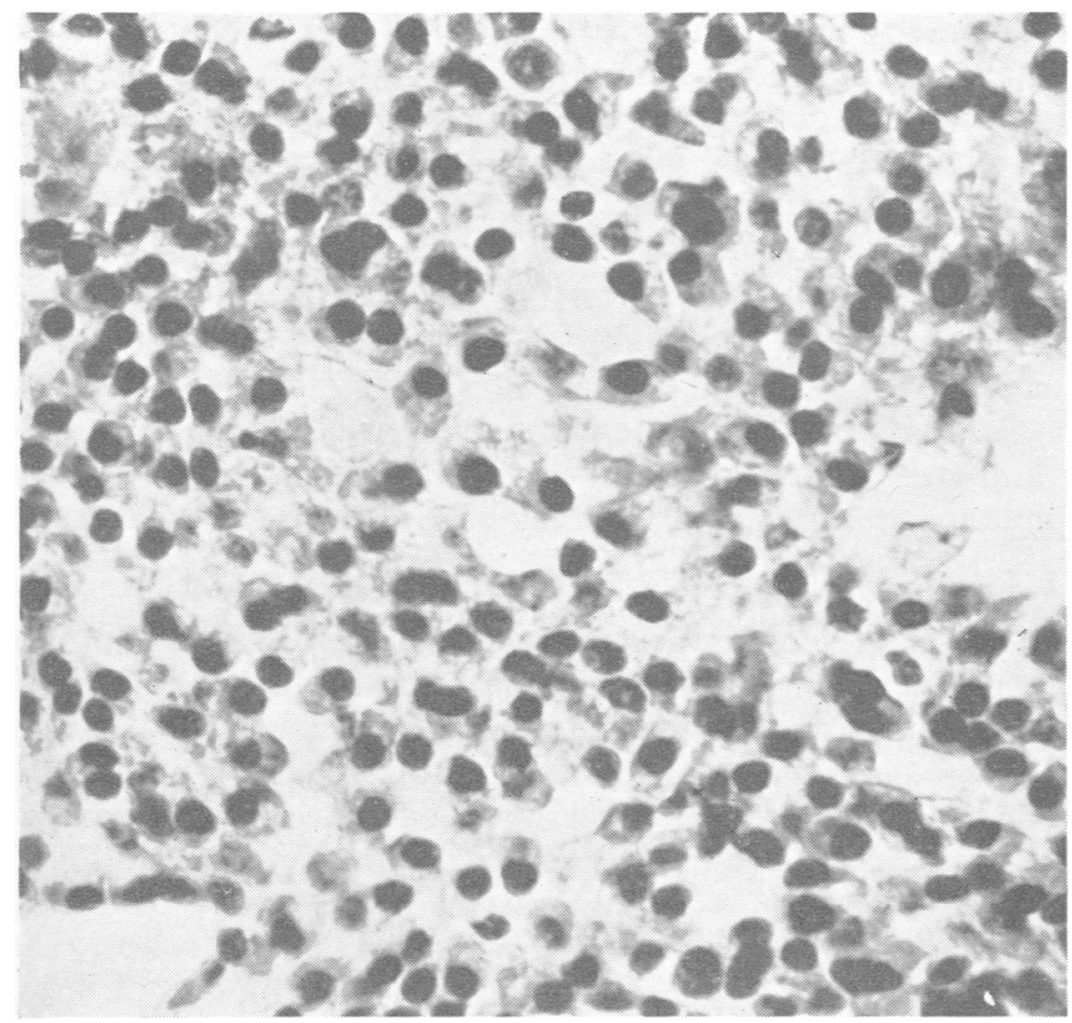

Fici. 5.-Case 2, ஜ photomicrograph of $\vec{\circ}$ frontal bone myeloma. The tumour consists $\vec{\omega}$ mainly of plasma cells. $(\times 580)$

First Operation (5.4.38) Sir Hugh Cairns and Mr. J. B. Pennybacker. The tumoươ although a product of the bone, was firmly attached to the dura mater which was intact except for two areas at the centre of the tumour where the myelomatous tissue had extended $\overline{0}$ through it. An attempt was made to remove the tumour, but partly because of its vascul- $\frac{\mathscr{D}}{\mathbb{D}}$ arity (ligation of the ipsilateral common carotid artery did not help) and partly because $\varrho$ of its adherence to the dura, this was only partially successful.

Progress.-The following day the patient was comatose and had a right hemiplegia, $\stackrel{3}{\vec{T}}$ and as there was no improvement a second operation was carried out on April 7, 1938. The left frontal lobe was very oedematous and a portion of it was removed. There was $\frac{0}{0}$. some temporary improvement, but she did not regain consciousness and died 2 days later. $\frac{}{0}$

Autopsy (J.R.C.).-The remnants of the myeloma were found and it was seen that $\frac{3}{\circ}$. tumour tissue had invaded the left frontal, left ethmoidal, and right frontal sinuses, and $\stackrel{\bigcirc}{\Omega}$ that there was a defect in the roof of the orbit, with growth on the surface of the orbital fascia displacing the contents. The bone marrow was normal to macroscopical examination in the sternum, vertebrae, one humerus, ribs, and other bones. No other abnormai features were detected.

Comment.-The myeloma in this case had grown from the frontal bone to involve the os orbit secondarily, and although it was single, the presence of Bence Jones proteinuria indicated a more widespread process. Nevertheless it was felt that surgical intervention ${ }_{0}^{\omega}$ was justified, but the difficult operation illustrates the hazards of attempting complete ${ }_{0}^{2}$ excision of these neoplasms. As in the cases of Morax (1919) and Fuerster and Zuckerman $\frac{\mathscr{D}}{\mathbb{D}}$ (1950), there was a close relationship with trauma; Geschickter and Copeland $(1928) \stackrel{?}{\rightarrow}$ found a definite correlation in 20 per cent. of 425 cases of multiple myeloma.

Pathology.-All these cases had evidence of myelomatosis elsewhere and the $\stackrel{\vec{\otimes}}{\mathbb{R}}$ frontal or temporal tumour was usually noticed before the orbit was invaded. The $\stackrel{\mathbb{2}}{2}$ 
ocular features produced thereby were similar to those already considered in the preceding group. The outcome was much the same as in any other case of multiple myeloma, death being invariably due to generalization of the disease, which, in fact, was frequently already present when the cranial tumour appeared. Treatment seemed to have little or no effect upon these patients, the methods used being the same as in the previous group.

Myelomata of the bone of the skull base extending forward into the orbit and behaving like space-occupying lesions have been described by Rustizky (1873), Hoffmann(1904), Heilmann(1928), Seemann (1930), Piney and Riach (1931, Case 1), and Christophe and Divry (1940, Case 1). The clinical picture is usually complex because cranial nerves and structures other than the orbit are involved, but in at least one of them (Seemann, 1930) the initial diagnosis was that of. malignant orbital tumour.

Mucous Membrane.-One of the commonest extra-osseous sites for myelomata is the mucous membrane of the upper respiratory pathways, although here as with the ocular structures there has been considerable confusion caused by authors failing to differentiate between plasma cell myelomata and plasma cell granulomata (plasmacytomata). Ringertz (1938) surveyed 391 neoplasms arising from nasal, paranasal, and pharyngeal regions, and found eleven plasma cell tumours, although it is possible that some were not myelomatous. Nevertheless, although distortion from a distance was common, none is recorded as having invaded the orbit. The patient reported by Hajek (1926) had a myeloma of the frontal and ethmoid sinus, and this had also occurred in the right orbit of a patient reported by Holm (1932) Fuerste and Zuckerman (1950) described a case with a myeloma of the antrum which grew to an enormous size with orbital invasion and hideous facial disfigur ation. The myeloma grew from nasal or sinus cavities in the cases of Pallestrini (1927), Saarni (1933), and Tokumitsu and Takigawa (1936, Case 2); in the last, there was bilateral orbital involvement, a feature which was present also in the patients of Holm (1932) and Dick (1904). A case described by Greenfield (1948) is interesting, for a naso-pharyngeal myeloma is said to have extended to the orbit but, as no radiological or pathological proof is presented, it is possible that there was more than one myeloma present. The first indications of cranial involvement in these cases were symptoms referable to the nose, and nasal obstruction predominated; it was thus possible to detect the site of origin of the myeloma. As with the cranial bone myelomata, the ocular features developed later but were in no way distinctive except that as with any other tumour originating from the nose or sinus, the globe was displaced forwards and laterally. The local spread of myelomatous tissue was usually extensive but, apart from the case of Pallestrini (1927) where meningitis was the terminal event, death was due to the generalized disease as much as the cranial myeloma. As in the other cases of orbital myeloma, treatment is not very helpful, especially as the lesions are often deep as well as invasive. The measures described already are adopted.

\section{SUMMARY}

The orbit is occasionally involved in multiple myelomatosis, and symptoms and signs of an orbital space-occupying lesion produced by a plasma cell 
myeloma may be the first manifestation of this disease. The orbital myelomata are of two types:

A. Primary.-The clinical picture is that of an orbital tumour and the myeloma grows from the contents or confines of the orbit.

B. SeCONDARY.-The patient has a myeloma of adjacent bone or nasal or sinus cavities and later develops features of orbital invasion.

An example of each variety is described and pathological, clinical and therapeutic aspects are discussed.

My thanks are due to Mr. J. B. Pennybacker for allowing me to publish the case records of the two patients, and also for his valuable advice and criticism.

\section{REFERENCES}

Bayrd, E. D., and Heck, F. J. (1947). J. Amer. med. Ass., 133, 147.

BeLLER, A. J., and KoRnBlueth, W. (1951). British Journal of Ophthalınology, 35, 220.

Bichel, J. (1950). Ugeskr. Laeg., 112, 790.

BirCh-HirSCHFELD, A. (1930). "Die Krankheiten der Orbita." Chap. 13 in "Handbuch der gesamten Augenheilkunde ", ed. Graefe and Saemisch, vol. 9 (part 1). Springer, Berlin. Branham, V. C., and Lewis, N. D. C. (1921). Med. Rec. N. Y., 99, 169.

BuRNS, A. (1824). "Observations on the Surgical Anatomy of the Head and Neck", 2nd ed., pp. 386-392. Wardlaw and Cunninghame, Glasgow.

Christophe, L., and Divry, P. (1940). J. belge Neurol. Psychiat., 40, 279.

Christopherson, W. M., and Miller, A. J. (1950). Cancer, 3, 240.

Claisse, R., Bonduelle, M., and Lavergne, G. H. (1949). Sem. Hôp. Paris, $25,249$.

ClaRKE, E. "Cranial and Intracranial Myelomata". (To be published).

CRUicksh.ank, M. M. (1937). Brit.J. Surg., 24, 615.

DICK, G. F. (1904). Trans. Chicago path. Soc., 6, 168.

Driessens, François, P., Woillez, and Verdickt (1951). Bull. Soc. Ophtal. franç., p. 26.

Duc, C. (1937). Rass. ital. Ottalm., 6, 719.

FerRand, J. (1951). Bull. méd. Afr. occid. franç., 8, 43.

FLYNN, J., and SAILER, S. (1941). Ohio St. med. J., 37, 771.

Forrest, A. W. (1949). Arch. Ophthal., Chicago, 41, 198.

Françors, J., Kluurskens, J., and Rabaey, M. (1949). Ann. Oculist., Paris, 182, 729.

FuERSTE, F., and ZuCKERMAN, S. S .(1950). Arch. Otolaryng., Chicago, 51, 608.

Geréb, T., and KõnYves-Kolonics, L. (1950). Orv. Hetil., 91, 282.

Geschickter, C. F., and Copeland, M. M. (1928). Arch. Surg., Chicago, 16, 807.

GodTrRedSEN, E. (1944). Acta oto.-laryng., Stockh., Suppl. 59.

- (1947). Acta ophthal., Kbh., 25, 279.

Greenfield, M. M. (1948). Radiology, 50, 661.

Greenough, R. B., Simmons, C. C., and HaRmer, T. W. (1921). J. orthop. Surg., 3, 602.

Grósz, E. vON. (1927). Z. Augenheilk., 63, 309.

HAJEK, M. (1926). Beitr. Anat. etc. Ohr., 23, 465.

DE HARVEN, MURDOCH, and CAHEN (1927). Bull. Ass. franç. Cancer, 16, 287.

HeilmanN, P. (1928). Beitr. path. Anat., 80, 652.

HoffmanN, R. (1904). Ibid., 35, 317.

HoLm, E. (1932). Acta ophthal., Kbh., 10, 334.

Ibáñez Puiggari, M., Balado, M., and Gaviña Alvorada, E. (1930). Sem. med., B. Aires, 1, 781.

Krainin, P., D’Angio, C. J., and Smelin, A. (1949). Arch. intern. Med., 84, 976.

KrÜMmel H. (1950). Klin. Mbl. Augenheilk., 117, 620.

LeCĖNe, P. (1919). Ann. Oculist., Paris, 156, 249.

LANGDON, H. M. (1939). Trans. Amer. ophthal. Soc., 37, 223.

Lapoinre, A. (1929). Bull. Soc. nat. Chir., 55, 456.

Lutrgens, W. F., and Bayrd, E. D. (1951). J. Amer. med. Ass., 147, 824.

McEvoy, J. J. (1950). Arch. Ophthal., Chicago, 44, 163.

Mieremet, C. W. G. (1915). Virchows Arch., 219, 1.

Morax, V. (1919). Ann. Oculist., Paris, 156, 256.

(1926). "Cancer de l'appareil visuel ", p. 424. Doin, Paris.

Offret, G. (1951). "Les tumeurs primitives de l'orbite ", p. 268. Masson, Paris.

Pages, P., Betoulières, P., and Cazaban, R. (1952). Ann. Oculist., Paris, 185, 632.

Pallestrini, E. (1927). Arch. Sci. med., 51, 175.

Parker, S. T. (1937). Proc. roy Soc. Med., 31, 130. 
Pfeiffer, R. L. (1941). Trans. Amer. ophthal. Soc., 39, 492.

Piney, A., and Riach, J. S. (1931). Folia haemat., Lpz., 46, 37.

Przybylska, J. (1924). Ann. Oculist., Paris, 161, 198.

Quackenboss, A., and VerhoefF, F. H. (1906). J. med. Res.. 15, 261.

Ribbert, H. (1904). Zbl. allg. Path. path. Anat., 15, 337.

Ringertz, N. (1938). Acta oto-laryng., Stockh., Suppl. 27.

Rustizky, J. von (1873). Dtsch. Z. Chir., 3, 162.

SAARni, E. (1933). Arch. Ohr.-, Nas.-, u. KehlkHeilk., 136, 54.

Seemann, G. (1930). Zhl. allg. Path. path. Anat., 48, 212.

SCHEINKER, I. (1938). Dtsch. Z. Nervenheilk., 147, 247. (1951). "Medical Neuropathology ", p. 252. Thomas, Springfield, III.

ToKumitsu, K., and TAKIGAWA, K. (1936). Gann, 30, 387.

VERHOEFF, F. H. (1939). In discussion of paper by Langdon (1939).

Walsh, F. B. (1947). "Clinical Neuro-Ophthalmology", p. 1115. Williams and Wilkins, Baltimore. 